\title{
Privileged Comment
}

\section{The Ebitor Reviews the Elements in a Reconstruction LABOR Policy}

A FTER July 18, 1918, the tide of war was turning and it seemed entirely proper in October for the editor of a labor volume of The Annals to direct attention to those far reaching changes in our industrial life sure to follow a peace not indefinitely remote. No suggestion of pro-Germanism or weakening of morale could from then on attend a discussion of the problems of labor demobilization, labor placement, or labor standards which would affect the lives and productivity of workers in the postwar period. In time of war prepare for peace seemed a sensible dictum. Little risk was involved in the decision to focus attention on post-war rather than war labor problems. Events determined and have since justified that decision. Before this volume comes from press, certain parts of a reconstruction labor policy will surely be in effect. Thus does editorial prevision become historical reflection.

By November 1, 1918, it is accurate to say that no definitive and inclusive labor policy had been adopted in the United States for all workers employed in distinctly war industries. In England, reconstruction problems had long been under discussion by writers and special governmental agencies. A far-reaching program had been developed. When this volume appears, perhaps more than in November, the United States may need a comprehensive labor policy.

The real task of the editor proved to lie not in the decision to raise for discussion post-war labor problems, but in the selection of a name for the volume. It came into being under controls far more complex than those comprised in the Mendelian formula. It has grown in spite of adversity.

Whether the United States is facing a reconstruction or readjustment period is a question about which those who speak with authority do not agree. The new industrial creed enunciated by Mr. Rockefeller (p. 167), the labor program urged by Mr. Gompers (p.182), and the British Labor Party platform (p.187), show some- 
thing of contrast. If an examination of this entire volume is a fair index of the changes ahead-and certainly the greatest effort was made to avoid selection of topics or contributors which would emphasize a single viewpoint-little evidence is found of the desire to cut deep into the institution of private property or make other such fundamental changes as have been urged by British writers. $^{1}$ Perhaps Mr. McAdoo was not far wrong in his reported statement that "readjustment" rather than "reconstruction" describes the changes necessary in the post-war period. The word reconstruction, however, has current usage; whether the changes we are facing will become revolutionary is unpredictable.

The use of the expression "a labor policy" in the title of this volume, rather than such a phrase as "labor policies in reconstruction," perhaps indicates an editorial wish instead of the likely trend of events. President Wilson, before leaving the country to give his personal attention to the larger problems of international politics, made the following significant statement:

So far as our domestic affairs are concerned, the problem of our return to peace is a problem of economic and industrial readjustment. That problem is less serious for us than it may turn out to be for the nations which have suffered the disarrangements and the losses of war longer than we.

Our people, moreover, do not want to be coached and led. They know their own business, are quick and resourceful at every readjustment, definite in purpose and self-reliant in action.

Any leading strings we might seek to put them in would speedily become hopelessly tangled because they would pay no attention to them and go their own way.

All that we can do as their legislative and executive servants is to mediate the process of change here, there, and elsewhere, as we may.

I have heard much counsel as to the plans that should be formed and personally conducted to a happy consummation, but from no quarter have I seen any general scheme of "reconstruction" emerge which I thought it likely we could force our spirited business men and self-reliant laborers to accept with due pliancy and obedience. 2

That this position has met with approval is shown by such editorials as the one entitled "No Patent Remedies Are Needed to Adjust Labor," from which the following excerpt is taken:

President Wilson seems to see a little more clearly than some other observers, for he told Congress on Monday that the working of natural forces was likely in many cases to bring about readjustment of the country to normal conditions faster than any plans for it could be made in Washington. While he was not speaking particularly of the labor situation,

1 See for example: J. A. Hobson, “Democracy After the War," S. G. Hobson, "National Guilds" and G. D. H. Cole, "Self-Government in Industry."

2From President Wilson's address to Congress, December 2. 
there are known facts sufficient to justify the belief that there is likely to be immeasurably less friction in the reabsorption of the soldiers into industrial life and the employment of the war workers in peaceful industry than the alarmists have anticipated. ${ }^{3}$

A difference of opinion over demobilization is clearly indicated by Dr. Walter E. Weyl. "Planless Demobilization" is the title of the article from which the following excerpts are taken:

Here in America we are trusting to luck. We have been lucky before and see no reason why we should not be lucky again. In 1865 our demobilization took place planlessly and painlessly. Of course we are not as young as we were then, not as elastic or resilient, and we are far more industrialized. Still we have an easier task than has England or Italy and in any case there is a special Providence looking after our interests. Even if we wished to demobilize scientifically we should not have the necessary information.

Here is a very incomplete list of some of these things that we do not know:

(1) We do not know how many war workers there are. We do not know whether there are three millions or four millions or five millions or six millions.

(2) We do not know what facilities we have for bringing our overseas army home. We do not know whether we can physically do this job in four months, six months, eight months or twelve months.

(3) We do not know what positions are or will be available for the men who will be discharged.

(4) We do not know how many extra men the railroads can absorb either in operation or in new construction. We do not know whether they can absorb one hundred thousand or two hundred thousand or three or four or five or ten hundred thousand men. We do not know how many extra men can be absorbed by the building trades, by the textile industries, by shipbuilding.

(5) We do not know how many men and women in these and other industries will voluntarily give up their present positions or will be displaced or can be displaced. We do not know how many men and women are employed in these industries. We know nothing about the extent of the dilution of labor.

(6) We do not know anything concerning the immediate future of American industry. We know next to nothing about the home demand for its products. We know still less about the foreign demand. We do not know to what extent the foreign demand for raw products, if it exists, can be financed. We do not know to what extent the recuperation of American industry will be limited by the supply of raw materials, by the reduction of shipping, by the impoverishment of Europe.

To sum up the situation we are running new risks simply because we have not studied the problem or realized that there was a problem. We are like the statesman who believed that an army could be created over night by a million men springing to arms. He thought of mobilization as an adventitous gathering of a million freemen, each with his fowling piece. We are still thinking of demobilization in loose icrms. But demobilization is a highly technical process; military demobilization means industrial mobilization. It is

${ }^{3}$ Since this editorial the same paper has been featuring stories of the inability of a few discharged soldiers to find employment in this same community where natural forces would bring readjustment to normal conditions faster than any plans could be made in Washington. 
primarily a civil or industrial, not a military task; it is a scientific task, requiring order, discipline and synchronization, and above all, forethought."

If the tenor of the papers in this volume is again significant, it would seem that the editorial wish for a reconstruction labor policy is shared in rather generally by the contributors - men who have viewed our reconstruction labor problems from the closer range of personal experience.

During the war it is safe to say that we modified the concept of individual pecuniary gain and the idea that money would buy goods somehow, somewhere. We realized, perhaps imperfectly, that the war had to be financed from the current national income. We were interested in determining "on what the productivity of the productive factors depends." We divided the less essential from the more essential businesses for regulatory purposes. The slogans, "business as usual," and "buy a bond and pass it on, "were discarded, along with our reliance upon the slow-going adjustments under an unregulated law of supply and demand. All this and much more occurred under war pressure. "We thought and acted as a nation instead of a million sightless autonomous units."

'The "post-war mind" must, of course, be considered in reckoning on the probability of establishing a comprehensive national labor policy. Human instincts involved in man's behavior are stimulated very differently by peace and war conditions. "A reconstruction labor policy" will cause less of a thrill than did marching troops or "win the war." Especially is this so when most of us have acquired the habit of individualistic activity; we "do not want to be coached and led." However, with mobilization of our industrial life a national achievement, it does seem that the release of man power for post-war industry and the placement of labor, if not the standards for replaced labor, offer a problem truly nationa!, requiring more than readjustments under the old oppbsition of interests partly repressed by the calling forth of a war feeling. It does seem that far-reaching national prevision and provision are required, and that there should be at least the fullest utilization of existing machinery to avoid a period when men may "hunger, worry, suffer, go to pieces." It does seem that national readjustments should not be left mainly to

4he New Republic, November 80, 1918. Pp. 125-127. 
individual or group interest,-or disinterest. The wish for a comprehensive reconstruction policy regarding labor takes on all the fervor of a political prayer.

Assuming no overthrow of the institution of private property, or other such fundamental changes as have been suggested in certain quarters,--assuming that a readjustment rather than a reconstruction labor policy is the problem we are facing, we can group the elements of such a policy under three main heads, corresponding roughly with the order in which our labor problems will arise. Man and woman power will be released from war activities for post-war industry. The problem of the transition period then becomes that of labor placement and labor assimilation. Labor standards for replaced labor constitute a third and continuing group of questions far more important than the passing changes accompanying a return to peace conditions in industry. The papers in this volume are arranged in the order just indicated. But before reviewing the elements in a reconstruction labor policy it may not be amiss to note one point,--elaborate machinery, such as England boasts of, may not be an indispensable part of the formulation or execution of a national labor policy. "Made in America" is likely to evoke a more favorable response, although the British plans may suggest methods for us which should not be passed over thoughtlessly.

In some quarters it was feared that the demobilization of our troops might be carried on in some mathematical, mechanical way which regarded the convenience of the army rather than the needs of industry, the occupational qualification of the soldier, geographic diffusion, or domestic obligations. The first paper of this volume (p. 1) contains a discussion of army demobilization which should come to some better end than a pigeon-hole in a War Department desk.

Release of man power for post-war industry calls to mind not only the mustering out of soldiers but the release of industrial leaders from government service (p. 13). This process carries with it an interest commensurate with the conspicuous position held by these men and the possibility of their great influence when they return to their peace occupations. That the release of industrial leaders is significant for business and labor adjustments is a manifest proposition, but will they go back to business pur- 
suits with a new national viewpoint regarding production and a desire to coöperate in establishing such interrelationship of government and business as is necessary for the public weal under even a peace régime?

Even though "we know nothing about the extent of the dilution of labor," it would be most helpful for the formulation of a reconstruction labor policy to have a clear cut statement as to the position of both labor unions and employers regarding the retention of unskilled workers substituted for skilled labor, women drawn into men's work, and children recruited for industry under war pressure and a favorable decision of the Supreme Court. Repeated efforts were made to ascertain the attitude of responsible labor union officials and employers regarding possible displacement of women, unskilled workers and children who were drawn into the industrial ranks as a war measure. Such information would make surer any steps necessary to prevent a serious condition of maladjustment both in the release of man power for post-war industry and industrial placement.

It would be helpful also-if a comprehensive government policy were likely to be formulated regarding post-war readjustments in industry-to have clearly set forth the policies of government corporations in releasing labor. The government cannot fairly expect norms radically different from those it adopts in the case of its own employes to be acted upon generally by business men in the conduct of their private enterprises. Formal statements were not available.

Industrial placement suggests a query regarding existing agencies to connect the man and the job. "The organization of the United States Employment Service and its war achievements are indicated in the first paper in part two of this volume (p. 19). In spite of limitations and shortcomings incident to rapid growth, and in spite of current criticisms, we may still give ear to the plans already developed for the greater usefulness of the service during the post-war period. The service is national in its scope; the immediate problem of industrial placement is national in extent; we may reasonably expect effective adjustment of the United States Employment Service to this sudden problem of placing demobilized man power.

The lessons of the war in shifting labor from place to place or 
occupation to occupation should have a very real significance in working out the problem of industrial placement during the postwar period. Mistakes made in gathering together large groups of men in one locality without due regard for housing and local transportation facilities, mistakes made in recruiting workers without assembling materials needed, stand out in the memory of those of us living in the war industries sections of the Atlantic seaboard. Shifting workers from one end of the country to the other only to be sent back the next week was not conducive to labor efficiency. Recruiting labor as if a commodity-no questions asked so long as five to ten men appeared for each job at a given time and place --but aggravated both labor shortage and labor unrest. These and other mistakes of shifting labor are still fresh in our minds. Now that we are facing the problem of demobilizing the army and war industries-a problem of industrial mobilization which includes inevitable shifts of labor-we are entitled to competent counsel. It is the opinion of the Director General of the United States Employment Service (p. 28), that oldtime methods of recruiting labor by private employment agents, under methods which regard labor as a mere commodity, will unquestionably aggravate conditions of unemployment. While labor should not be put in leading strings, we may have full regard for the opinion that "mouth to mouth" information regarding labor requirements in various regions and industries will be inadequate and misleading, contributing in large degree to the already serious problem of floating labor. The attitude that the individual, unaided, is competent to find and choose his own job will often result in unemployment and misery. It seems reasonable, also, that commercial agencies and state employment organizations, unaided, are as likely to prove inadequate in shifting and placing labor during the post-war period as they were alleged to be under pressure of war necessity. The need for coördinated activity of all possible agencies the country over is a real need if the war has any lessons for us regarding the shifting and placement of labor. An adequate and effective national clearance service, based on community surveys of labor requirements and the coördinated activity of existing employment agencies, may not have a paternalistic compulsory feature, but it should go far toward preventing improper labor distribution, excessive turnover, floating labor, 
unemployment, unrest, misery. Recruiting, shifting, clearing labor, no matter how extensive the machinery for labor placement, will result in maladjustment, however, unless one error is guarded against, that of recruiting men unfitted for the work they wish to do. Here lies the importance of trade tests and a uniform classification of jobs already available for the use of labor-placing agencies.

The use of army tests in rating general intelligence and trade skill (p. 38) has been one of the notable innovations of the war. Reliance on these tests in the army for bringing man and job together and equalizing units for development purposes, suggests the possibility of the extension of psychologic tests for the scientific placement of labor in post-war industry. The selection of men for particular jobs could very easily be made more effective if one basis for selection generally adopted in industry were a rating on general intelligence and technical skill. Moreover the shifting of employes from department to department, the picking of individuals for further training, and the reduction of costly labor turnover are among the possibilities suggested by Dr. Ruml, who has first hand experience with the operation of army selective tests. His warnings regarding their use by employment managers are not the least important part of his contribution. Some psychologists, to be sure, are still doubtful regarding the efficacy of group tests as compared with individual tests. The devising of satisfactory psychological tests for many purposes is still in the experimental stage. The development of this work, however, gives promise of a large increase in the effectiveness of employes, if indeed it does not mark the beginning of a new period in vocational and educational guidance. No reconstruction labor policy will be well considered if it does not include the extension of selective tests to labor placement in peace time.

That war pressure has given emphasis to personnel problems in industry (p. 47) requires no extended demonstration. Broad gauged organization and supervision of labor alone will prevent labor adjustments from becoming the very storm center of a possible clash between radicals and reactionaries. Employers have chafed under wage increases accompanied by no marked increase in labor efficiency. Certain limited groups of employes, especially in war industries, may have secured a surplus over 
and above a basic living standard through a monopoly power conferred by their ability to do damage to industry,-if only through witholding their labor unless demands were met. Cost plus contracts did tend to retard wage increases which were not necessarily connected with productive efficiency. Employers, smarting under increased wages unaccompanied by increases in production, are not likely to make labor readjustments easy if they adhere to an "obstructive philosophy." Those labor leaders who adhere to a "destructive philosophy" likewise can prevent the readjustments necessary in the coming days. Upon personnel departments or employment managers will devolve in no small measure the work of placing men in industry and avoiding labor disturbances over wages and labor standards.

One of the parts of a reconstruction labor policy that is receiving more than ordinary attention at this time is the establishment of buffer employment during the reconstruction period. Mr. Mallery, who has long been working on this problem of buffer employment, has set forth his project (p. 56), to utilize public works in the stabilizing of employment. He occupies, moreover, a position which gives him opportunity to demonstrate more fully the importance of this part of a reconstruction labor policy.

Placing soldiers in farm colonies (p. 62) is a plan which has received not only the attention of the Secretary of the Interior, but has been accorded full co'nment in the President's last message to Congress. Just what that plan is will be far more intelligible after reading the exposition of it in this volume by its sponsor.

One hesitates to take the rôle of critic when he finds that parts of a reconstruction labor policy are actually in process of development and execution. The placement of soldiers mustered from army service may very well be expedited through the use of public works for buffer employment and the development of farm colony projects. The placement of war workers in general may be greatly furthered through the activity of the United States Employment Service.

Housing and local transportation facilities in relation to labor placement aroused more than usual interest during the war. A long time view of this same problem (p. 51) really raises for consideration one of the labor standards discussed in the third section of this volume. 
The problem of industrial placement is sure to be affected by whatever immigration standards we may adopt for the post-war period. However "liberal" one may be, or however "internationally minded," he is likely to be conscious of conservative feeling and national sentiment in considering the possible effect of immigration upon an American standard of living. Labor placement in this country may not be complicated by the "dumping" of crippled and unfit workers; a problem, however, exists in maintaining immigration standards for able-bodied workers. But it is unnecessary here to redevelop the thesis set forth (p. 73) in the article on "Immigration Standards after the War."

"Seven Points for a Reconstruction Labor Policy" (p. 80) is the title the editor made free to prefix to an article summing up the views of a writer whose first-hand experience with the problems of labor standards during the war give him ground for indicating certain fundamental propositions regarding standards for replaced labor.

With the influx of women into industry, one aspect of a reconstruction labor policy most certainly has to do with labor standards for women. The classic report of the British Health of Munition Workers' Committee included a noteworthy section treating of conditions under which women should work. The standards set up by the Woman in Industry Service of the United States Department of Labor (p. 87) are deserving of equally close study for the determination of a federal labor policy during our post-war period. With one-fourth of the workers of the United States women, a "condition and not a theory confronts us." It may shock us to realize that the economic function of women as controllers of consumption is now but part of the story; women have come into our man-made industry as co-workers if not competitors. Changes in economic doctrines and business organization are the inevitable concomitants of that fact. Full hearing is needed for the woman's point of view when she is sure to play a doubly important part in our economic life.

The short run problem of women in industry is that of "diluted labor." A view urged by a writer whose position alone would give her hearing is that "the right of the returned soldier to his job is not a labor policy upon which to build a program. for women in industry." She contends that the reconstruction needs of in- 
dustry will require the utilization of all available man and woman power. What view will obtain with employers and labor unions regarding diluted labor is, however, not yet clear and the immediate problem merges in the long run question regarding the jobs which should be reserved exclusively for women workers. A clear cut program regarding woman's work in industry would go far toward making diluted labor adjustments easier.

One point is fairly clear, however, about diluted labor. Those who assumed that women factory employes will shift en masse to domestic service, are overlooking some human instincts that have been stimulated by war conditions. The long hours, isolation, and self abasement attached to domestic employment will have small appeal compared with freedom after a standard workday, group feeling in the factory and the fuller play of the self-assertive tendency in human nature which has been made possible by industrial employment. Psychic income may be received directly from employment as well as indirectly through goods purchased with even high money wages from domestic service. A considerable number of housewives will have a continuing interest in electric washers and vacuum cleaners. And what applies to domestic service may apply in some degree to a giving over of industrial employment to return precipitately to the former occupation of matrimony. The detached observer may count on the age-long sex instinct, but it will be surprising indeed if some curious compromises are not effected.

Women are in industry in larger numbers than ever beforemany of them to stay, at least long enough each generation to constitute a problem. To the old three-fold division of laborgeographic, occupational, and division of tasks within an occupation-it has been suggested that a fourth be added,--sex division of labor. Advocates of such specialization assure us that this new division of labor will not be based on the formulae "woman's place is in the home" and the "inherent difference of woman's mind"; whether women should do the same work as men is a question predicated on physiologic differences. Women have been doing an undreamed-of number of men's jobs, with perhaps slight modification of machinery and working conditions. This new work was undertaken because of war pressure, and it is perhaps doubtful whether it has been carried on long enough even 
by the women of England to determine the long run physiologic effects. The close connection between woman's physical make-up and the nature of her work was so clear that proper safeguards were devised for her employment in many instances, if indeed she was not altogether excluded from particular jobs. It has been urged that perhaps a sex division of labor should be worked out which would throw open to women in general the light, replaceable jobs. This theory assumes that women should not undertake work beyond their physical strength, nor should they usually be looked upon as a first source of labor when the work desired would require the uninterrupted activity of a highly trained and specialized worker. In $1910,6,150,569$ women gainfully employed in the United States were between sixteen and forty-four -child-bearing years. Under such division of labor, women would be co-workers with rather than competitors of men. The general adoption of such a policy would bring about a new set of non-competing labor groups, and after a time it would be as unpopular for the much talked-of "he man" to run elevators, sell ribbons, or occupy one of the light replaceable jobs as to carry knitting implements in a street car. Such a change, of course, is dependent upon the development of public opinion rather than the establishing of elaborate government machinery. Men would have their own bailiwick; they would do the heavy work in industry and hold those positions of the less replaceable kind.

The sex division of labor here sketched is of course likely to be accorded first place in an unpopular review, especially by those women who certainly have the training and qualities for executive work, and who look forward to a career without the field of matrimony.

That there are physiologic differences between men and women sufficient to warrant the non-entrance of the latter into particular occupations is an undisputed fact. No group more keenly appreciates this fact than do women themselves nor does any other group place a higher premium upon the health of women as the greatest factor in the efficiency of the industrial worker and in the development of the home-maker and mother of the future. But such physiologic differences afford no justification for a sex division of labor which may be advanced as one of the methods of labor adjustment in the post-war period. By eliminating women as the competitors of men, even in a restricted group of occupations -in a word, by "manizing" some occupations and "womanizing" others, a blow is struck at the industrial morale of American womanhood. Regardless of the sincerity of motive which may underlie such a theory, it is bound inevitably to mean a destruction of the initiative of that group of women, admittedly the minority group, whose training and qualities are such as to make them as executives the peers of men. And there will be an effect, 
equally pernicious, on the majority group of industrial workers by the inhibition of their desires and judgments. Admitting that sufficient physiologic differences do exist to warrant the exclusion of women from particular occupations, let us face likewise the fact that the physical incapacities of some men warrant also their exclusion from particular jobs. And with this as a premise let us add to the trade and intelligence tests, now an accepted prerequisite in many occupations, physical tests which will eliminate those men and those women from enrollment in the occupations for which they, for any reason, are not fitted. By this method we are putting employment upon the only basis where it should rest-a basis of physical and mental fitness for a particular job without regard to sex.

The causes of labor unrest (pp. 95 and 101) that appeared during the war, were accentuated aspects of continuing sources of labor disturbance. In determining standards for replaced labor, full thought must be given not so much to paliatives as to the elimination of deep-rooted maladies in our industrial society. "Can We Eliminate Labor Unrest" is the title of the article setting forth in concrete form standards which make clearer an affirmative answer. Where the focal points of labor unrest are likely to be found is emphasized in the paper on "Post-war Causes for Labor Unrest." Knowing the probable causes of conflict, it will be easier to formulate a reconstruction labor policy which will look to the avoidance of those outstanding causes of labor unrest.

So acute a cause of labor unrest is the inevitable problem of wages that separate treatment has been accorded it. As a war problem the importance of determining an American standard of living has been forced on our attention by the upheaval in prices and the necessity of adjusting money wages to increased living costs. Not only has the Labor Party of Britain gone on record as favoring a basic living standard for the nation, but our National War Labor Board has determined wage disputes on the principle that all workers are entitled to a standard "which will insure the subsistence of the worker and his family in health and reasonable comfort." Clear expression has been given to the doctrine that there is a standard of living necessary to the productive efficiency of wage workers. Wages of various groups over and above this basic standard may constitute a surplus traceable to strategic advantage or monopoly power. The surplus may or may not contribute to increased efficiency of labor, but theories of wages seem lately to have been modified to fix a minimum below which the worker cannot be expected to give effective service. In reckoning that part of the national income which could be devoted to 
war purposes, students of public finance placed as a necessary limitation on war expenditures the setting aside of a sufficient fund to maintain the energy of the people. A human maintenance fund and a capital replacement fund are indispensable requisites of efficient post-war production.

Just how a standard of living connected with productive efficiency could be determined was sometimes considered a matter of mystery beyond the comprehension of all but economists. That delusion must certainly give way before the treatment of budgetary studies in the article entitled "Measurement of the Cost of Living and Wages" (p. 110). It is a bit of privileged comment for the editor to state that Professor W. J. Ogburn has stripped of its mystery the science of budget construction. It is of more importance for most of us to have some clear cut idea of the method of measuring the cost of living and the actual increases in American living costs, than to follow an involved discussion of perhaps minor points of budget study. It is, however, but another bit of privileged comment to raise a question regarding the regular assumption of a family of five which may not always square with the facts. Thus in one state the average family may be 4.7 or in one large labor group 3.86. Budgets are constructed to make adequate provision for a family of five in order that families of subnormal size may find it possible to increase to the normal limit without suffering a lowering of their customary living standard. This practice is justified on the ground of public policy. It is a matter open to argument at least whether increased family earnings necessarily insure family increase. The size of the fanily seems more often to vary inversely with the size of income, and an improved standard of living "does not come to fruition in a greater number of children." As a matter of scientific procedure in budget construction, in no way impugning the desirability of a normal family of five, the question may still be raised whether the old assumption will necessarily yield the desired result.

In connection with the study of wages in relation to living costs, it is noteworthy that there should be in this volume several positive clear cut statements that the wages of the chief bread winner should be adequate to afford a living standard for the entire family of five. In various studies the chief bread winner's earnings 
(husband) have constituted 46 per cent to 89 per cent of the total income of the family. It is urged, however, that earnings contributed by other members of the family group should not be reckoned as "complementary earnings" in the determination of wage scales.

One of the points of particular interest to economists in Professor Ogburn's paper is the outlining of pioneer work to express a budget in quantities rather than only in prices. The advantages of having a unit basis for a living standard are clear, when one considers price variation from place to place and time to time. Such a quantity budget will have importance for the establishing of a basic efficiency wage almost irrespective of particular times and particular places.

Equal pay for equal work is the basis urged for the determination of wages for women workers (p. 123) and certainly in one instance brought to the editor's attention the formula was more than justified. Three conductorettes and three conductors had alternate cars on the same street railway line the same day. The office returns showed that the day envelopes of the women contained something like twice the fares turned in by the men. Generalization, however, as to woman's initiative or efficiency would scarcely be warranted on the basis of this single test.

Without being disposed to question the suggestion of equal work-equal pay, one can still raise the query whether the problem of wages under a sex division of labor would not be equally simple. If instead of conflict between men and women for the same jobs and pressure for acceptance of the doctrine equal work - equal pay, sex division of labor were established, it would but set up additional non-competing groups, and wages for women as for men would be determined on the basis of a living standard with any surplus secured through collective bargaining or strategic position.

Health standards for labor (p. 130) are clearly comprehended in a reconstruction labor policy. Fatigue, hours of work, housing, working conditions are subjects inseparably related to productive efficiency and human welfare, as are hazards of women's work and the problem of the child in industry. One suggestion made in the paper entitled "Health Standards for Labor" is deserving of more than editorial discussion. If part of the task of connecting the man and the job may involve trade and intelligence tests, another 
surely requires physical tests for the fitness of workers. It is not enough that women should not be permitted to engage in work beyond their strength-it is definitely necessary that men should not be enrolled in occupations for which they have not the physical capacity. The establishment of the practice of subjecting candidates for work to a physical examination would undoubtedly meet with opposition, but, should public opinion crystallize regarding that standard for the post-war labor force, proper legislation and, indeed, administrative machinery could speedily be devised. It would perhaps work a hardship in the case of adults to have such a plan develop as part of a reconstruction labor policy, but the situation would be less complex in the case of youths entering occupations which might be detrimental to health and development. Health standards for labor include not merely the reducing of hazards to a minimum and increasing the productive capacity of the individual,-they may even be made a basis for vocational guidance and the encouragement of young men to start in work for which "he-men" are qualified.

Vocational guidance leads directly to the consideration of industrial training after the war (p.137). The use of the United States Training Service to fill labor prescriptions on the basis of skill acquired during the war, has given new emphasis to participation by the federal government in the work of industrial education. While one may quarrel with the implications of "specific productivity" in the idea that the maintenance of wages is "dependent on the relative production of the individual worker," or the maintenance of the national average output, he can nevertheless endorse the opinion that industrial education over and above special training by industrial concerns is truly a national need. The rôle of the employment manager in vocational guidance must not, however, be overlooked (p. 144).

In closing his comment the editor may be permitted to note that the War Emergency and Reconstruction Congress of the United States Chamber of Commerce, recently in session at Atlantic City, was a gathering of national interest (p. 148). The attitude of business men towards post-war standards for industrial relations (p.163) will count heavily in the determination of a reconstruction labor policy and the setting of labor standards during the reconstruction period. That the old order of tooth 
and claw struggle between organized business and organized labor cannot result in the future political and social stability of the nation, or, indeed, the industrial prosperity of this great country, was clearly recognized by one of the outstanding speakers at the business man's congress (p. 157). By their acts will they truly speak!

It is the editor's special privilege to make grateful acknowledgment to Mr. V. Everit Macy, Dr. Royal Meeker, and Mr. Paul T. Beisser for their good offices in helping to suggest topics and contributors for a labor volume. More than editorial courtesy was shown by Mr. Thorpe, editor of the "Nation's Business," and Mr. Kellog, editor of the "Survey," in permitting the publication of certain of the papers of this volume. Above all acknowledgment is due to those busy men and women who made personal sacrifice of time and effort to prepare papers developing "A Reconstruction Labor Policy."

C. H. Crennan. 